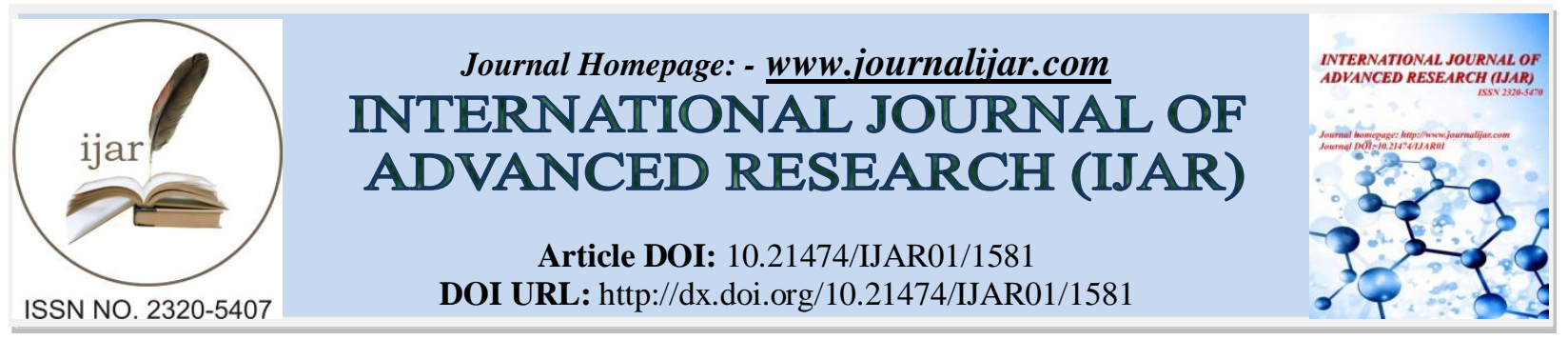

RESEARCH ARTICLE

\title{
MANAGEMENT OF FEMALE INFERTILITY (LOW OVARIAN RESERVE) W.S.R TO ANOVULATORY FACTOR BY KALA BASTI AND UTTAR BASTI- A CLINICAL CASE STUDY.
}

\section{Dr. Jatinder Kour ${ }^{1}$ and Dr. Shilpa B. Donga ${ }^{2}$}

1. Second Year Ph.D. (Ayu.) Scholar, Department of Streerog \& Prasutitantra, I.P.G.T. \& R.A., G.A.U., Jamnagar, Gujarat, India.

2. Associate professor Department of Streerog \& Prasutitantra, I.P.G.T. \& R.A., G.A.U., Jamnagar, Gujarat, India.

\section{Manuscript Info}

(..........................

Manuscript History

Received: 19 July 2016

Final Accepted: 23 August 2016

Published: September 2016

Key words:-

infertility, anovulation,

kalabasti,uttarbasti.

\section{Abstract}

Infertility ${ }^{\mathrm{i}}$-The inability of a couple to conceive after one year of unprotected intercourse.The female factors for infertility are ovulatory factors (35\%), tubal factors(30\%), endometrial factors(21\%), uterine factors $(14 \%)$.Here in this case study I selected a case of infertility having anovulation due to low ovarian reserve. In the modern medicine they have not any particular treatment instead of giving hormonal therapy.According to ayurvedic classics Artav is the Updhatu of Rasa Dhatu and again Artava has all the qualities of Shonita(Rakata). Under Artava;menstrual blood and Ovum are included. Drugs used in the treatment of the patient mentioned by Charkacharya may have properties of both Rasa \& Raktshodhan and also helps in the formation of raja(ovum) and normalization of menstrual cycle. So 1 patient has been selected having infertility for 3 years with secondary amennorhoea and very low ovarian reserve (low AMH - <0.010). So here management with kala basti and uttar basti selected and it has been proved to be a very very effective treatment modality to treat anovulation.

Copy Right, IJAR, 2016,. All rights reserved.

\section{Introduction:-}

Infertility-The inability of a couple to conceive after one year of unprotected intercourse.It is of two types.Primary infertility-refers to couples who have not become pregnant after at least 1 year having sex without using birth control methods and Secondary infertility- refers to couples who have been able to get pregnant at least once, but now are unable .According to Acharya Sushrutai ${ }^{\text {ii }}$ four essential factors are required for healthy conception, which are proper fertile period, physiologically adequate and healthy internal organs of reproduction, the proper nourishment - to the developing zygote or fetus, the activated ovum and spermatozoa. Fulfillment of all the above essentials ensures the fullness of the motherhood. Any short come of the above factors impedes the conception and thus the motherhood of a woman. Among them Beeja is the core stone of the female reproductive process and in its absence conception cannot achieve despite of all the other factors. Here the Beeja is taken as Antahpushpa i.e. ovum. So anovulation can be included under Beeja Dushti.so in our classics the basti is well defined by acharyas and it is well acting for the anuloman of apan vayu which is the main vitiating factor genital system physiology.so here we selected the basti treatment for the infertile patient with low ovarian reserve.

Corresponding Author:- Dr.Jatinder kour.

Address:- Final Year Ph.D. (Ayu.) Scholar, Department of Streerog \& Prasutitantra, I.P.G.T. \& R.A., G.A.U., Jamnagar, Gujarat, India. 


\section{Drug review:-}

We used here kala basti ${ }^{i i i}$ and uttar basti.-drugs selected in both bastis are anubhutta yoga used in our opd and ipd.

\section{So ingredients of kala basti are-}

* Anuvasana basti-Dashamoola taila(60ml)

* Asthapana basti -

* Sneha - Dashamoola taila $(60 \mathrm{ml})$

* Kalka - shalaparn ${ }^{i v}$ i(5gm) (Desmodium gangeticum),

- Prishanparn ${ }^{v}(5 \mathrm{gm})$ (Uraria picta),

- Brihati $^{\text {vi }}$ (5gm) (Solanum indicum),

- Kantkari $^{\text {vii }}$ (5gm) (Solanum xanthocarpum)

- $G_{\text {- }}$ shru $^{\text {viii }}(5 \mathrm{gm})$ (Tribulus terrestris)

- $\quad B_{i l v a} a^{i x}(5 \mathrm{gm})$ (Aegle marmelos),

- $\quad$ Shyonak $^{x}(5 \mathrm{gm})$ (Oroxylum indicum),

- Agnimanth $^{x i}$ (5gm) (Premna integrifolia),

- Gambhari ${ }^{x i i}$ (5gm) (Gmelina arborea),

- Patala $^{x i i i}$ (5gm) (Stereospermym suaveolens),

* Kwatha - Dashamoola Kwatha(250 ml)

* Madhu - $60 \mathrm{ml}$

* Saindhava-5gm.

* Ingredients of uttar basti-uttar basti was also given by dashmoola taila.

Ingredients of dashmoola ${ }^{\mathrm{xiv}}$ -

\begin{tabular}{|c|c|c|c|c|c|c|c|}
\hline Drug name & Latin name & Rasa & Guna & Virya & Vipak & $\begin{array}{l}\text { Dosha } \\
\text { karma }\end{array}$ & Pradhan karma \\
\hline 1.Shalaparni & $\begin{array}{l}\text { Desmodium } \\
\text { gangeticum }\end{array}$ & $\begin{array}{l}\text { Madhura, } \\
\text { Tikta }\end{array}$ & $\begin{array}{l}\text { Laghu, } \\
\text { Snigdha }\end{array}$ & Ushana & Madhura & $\begin{array}{l}\text { Tridosha } \\
\text { shamak }\end{array}$ & $\begin{array}{l}\text { Balya,Shonitsthapan,Sh } \\
\text { othhara. }\end{array}$ \\
\hline 2.prishanparni & Uraria picta & $\begin{array}{l}\text { Madhura, } \\
\text { Tikta }\end{array}$ & $\begin{array}{l}\text { Laghu, } \\
\text { Snigdha }\end{array}$ & Ushana & Madhura & $\begin{array}{l}\text { Tridosha } \\
\text { shamak }\end{array}$ & $\begin{array}{l}\text { Balya,Shonitsthapan, Sh } \\
\text { othhara, } \\
\text { Anulomak }\end{array}$ \\
\hline 3.brihati & Solanum indicum & $\begin{array}{l}\text { Katu, } \\
\text { Tikta }\end{array}$ & $\begin{array}{l}\text { Laghu, } \\
\text { Ruksha, } \\
\text { Tikshan }\end{array}$ & Ushan & Katu & $\begin{array}{l}\text { Kapha } \\
\text { Vatta } \\
\text { shamak }\end{array}$ & $\begin{array}{l}\text { Garbashyasankochak,v } \\
\text { ednasthapak. }\end{array}$ \\
\hline 4.Kantkari & $\begin{array}{l}\text { Solanum } \\
\text { xanthocarpum }\end{array}$ & $\begin{array}{l}\text { Katu, } \\
\text { Tikta }\end{array}$ & $\begin{array}{l}\text { Laghu, } \\
\text { Ruksha, } \\
\text { Tikshan }\end{array}$ & Ushan & Katu & $\begin{array}{l}\text { Kapha } \\
\text { Vatta } \\
\text { shamak }\end{array}$ & $\begin{array}{l}\text { Garbashyasankochak,v } \\
\text { ednasthapak. }\end{array}$ \\
\hline 5.Gokshru & $\begin{array}{l}\text { Tribulus } \\
\text { terrestris }\end{array}$ & $\begin{array}{l}\text { Madhura, } \\
\text { Tikta }\end{array}$ & $\begin{array}{l}\text { Guru, } \\
\text { Snigdha }\end{array}$ & Sheeta & Madhura & $\begin{array}{l}\text { Vatta- } \\
\text { Pitta } \\
\text { shamak }\end{array}$ & $\begin{array}{l}\text { Garbhasthapan, } \\
\text { Vednasthapan, } \\
\text { Anulomak }\end{array}$ \\
\hline 6. Bilva & Aegle marmelos & $\begin{array}{l}\text { Kashaya, } \\
\text { Tikta }\end{array}$ & $\begin{array}{l}\text { Laghu, } \\
\text { Ruksha }\end{array}$ & Ushan & Katu & $\begin{array}{l}\text { Kapha } \\
\text { Vatta } \\
\text { shamak }\end{array}$ & Garbhashyashothhara. \\
\hline 7. Shyonak & $\begin{array}{l}\text { Oroxylum } \\
\text { indicum }\end{array}$ & $\begin{array}{l}\text { Madhura, } \\
\text { Tikta }\end{array}$ & $\begin{array}{l}\text { Laghu, } \\
\text { Ruksha }\end{array}$ & Ushan & Katu & $\begin{array}{l}\text { Kapha } \\
\text { Vatta } \\
\text { shamak }\end{array}$ & $\begin{array}{l}\text { Shothhara, } \\
\text { Vednasthapak }\end{array}$ \\
\hline 8.Agnimanth & $\begin{array}{l}\text { Premna } \\
\text { integrifolia }\end{array}$ & $\begin{array}{l}\text { Tikta, } \\
\text { Katu,Kash } \\
\text { aya }\end{array}$ & $\begin{array}{l}\text { Laghu, } \\
\text { Ruksha }\end{array}$ & Ushan & Katu & $\begin{array}{l}\text { Kapha } \\
\text { Vatta } \\
\text { shamak }\end{array}$ & $\begin{array}{l}\text { Vednasthapak, } \\
\text { Vajikara }\end{array}$ \\
\hline 9.Gambhari & Gmelina arborea & $\begin{array}{l}\text { Tikta } \\
\text {,Kashaya }\end{array}$ & $\begin{array}{l}\text { Guru, } \\
\text { Ruksha }\end{array}$ & Ushan & Katu & $\begin{array}{l}\text { tridoshash } \\
\text { amak }\end{array}$ & $\begin{array}{l}\text { Shothhara, } \\
\text { garbhasthapan. }\end{array}$ \\
\hline 10. Patala & $\begin{array}{l}\text { Stereospermum } \\
\text { suaveolens }\end{array}$ & $\begin{array}{l}\text { Tikta } \\
\text {,Kashaya }\end{array}$ & $\begin{array}{l}\text { Laghu, } \\
\text { Ruksha }\end{array}$ & Ushan & Katu & $\begin{array}{l}\text { tridoshash } \\
\text { amak }\end{array}$ & Vednasthapak, Vajikara \\
\hline
\end{tabular}


Treatment protocol-

For kala basti:-

\begin{tabular}{|c|c|c|c|c|c|c|}
\hline Procedure & Drug & Dose & Duration & Route & Method & Time \\
\hline Kala Basti & Dashmoola & $\begin{array}{l}60 \mathrm{ml} \text { oil for } \\
\text { (Anuvasan } \\
\text { basti) } \\
500 \mathrm{ml} \\
\text { (Asthapan } \\
\text { Basti) }\end{array}$ & 16 days & Gudamarg & $\begin{array}{l}\text { Anuvasan basti with } \\
\text { catheter. } \\
\text { Asthapan basti with } \\
\text { Enema pot. }\end{array}$ & Morning \\
\hline
\end{tabular}

For uttar-basti:-

\begin{tabular}{|l|l|l|l|l|l|l|}
\hline Procedure & Drug & Dose & Duration & Route & Method & Time \\
\hline UttarBasti & $\begin{array}{l}\text { Dashmoola } \\
\text { Oil }\end{array}$ & $5 \mathrm{ml}$ oil & 3 days & $\begin{array}{l}\text { Intra- } \\
\text { uterine }\end{array}$ & $\begin{array}{l}\text { Uttar basti with Uttarbasti } \\
\text { canula. }\end{array}$ & Morning \\
\hline
\end{tabular}

\section{Case study:-}

- 3 and 1/2 years before ie.Before marriage patient felt healthy but immediate after one month of marriage Pt. suffered from irregular periods since 3 years(i.e. periods came after every 6 months and 4 months) and are anovulatory periods, mild pain in abdomen .Duration of Her first menses after marriage was of 10 days and after 15 days her next menses came again.then after that no periods till 4 months.For the same symptoms pt. took the allopathic medicine for one and half year. Pt. treated with hormonal therapy tab.Ecosprin,ovabless, fertibex, ubiphene, progynova,ovacare,deviry,dexona etc.But pt had no improvement from these Complaints. So for ayurvedic treatment patient came in our opd one year before on 12/09/2015 and we did all the relevant investigations in which the - Serum T.S.H-6.999uiu/ml,Serum FSH-20.7miu/ml and AMH$<0.010 \mathrm{ng} / \mathrm{ml}$ (very low AMH value is the indicator of infertility)and in allopathy its is vey difficult to improve that.They even prescribe HCG injectables of 5000iu.so we started her treatment for infertility and irregular menses.And we planned for kala basti and uttar basti till the normalization of her cycle and an approach towards the increase of AMH level and ovarian reserve.

\begin{tabular}{|l|l|}
\hline \multicolumn{1}{|c|}{ PAST MENSTRUAL HISTORY } & \multicolumn{1}{c|}{ PRESENT MENSTRUAL HISTORY- } \\
\hline & LMP: 9/8/2016 \\
\hline DURATION: 4-5 Days & DURATION:3-4 Days \\
\hline INTERVAL: 4-6months & INTERVAL: 28-30 days \\
\hline & INTER MENSTRUAL SPOTTING : Absent \\
\hline REGULARITY: regular & REGULARITY: Regular Since 2 months \\
\hline AMOUNT OF LOSS: Moderate, P2 / day & AMOUNT OF LOSS: Moderate quantity , P2/day \\
\hline DYSMENORRHEA: Absent & DYSMENORRHEA: mild pain in back \& groin \\
\hline CHARACTER OF FLOW: Watery & CHARACTER OF FLOW: watery \\
\hline Colour - Normal red & Colour - Dark red \\
\hline
\end{tabular}

\section{Course of treatment:-}

1. Patient came to us 1 year before on $12 / 09 / 2015$ with the symptoms of Failure to conceive since $3 \& 1 / 2$ yrs and Irregular periods since 3 yrs.(immediate after the marriage)

2. Then we did all the relevant investigations in which the - Serum T.S.H 6.999uiu/ml,Serum FSH-20.7miu/ml and $\mathrm{AMH}-<0.010 \mathrm{ng} / \mathrm{ml}$.

3. We started kala basti having anuvasan basti and asthapan basti on alternate days for 16 days.

4. Then next month we gave uttar basti for 3 days.and after 3 days of basti her periods came and are still regular for the last two months.

Probable mode of action of Dashamoola Taila:-

According to the concept of Viryasamkranti (transformation of potency) described by Acharya Charaka, the potency of Dashamoola is already transferred in Dashamoola Kwatha, and the potency of Dashamoola in the Kalka form, on 
processing with oil, further causes the Viryasamkranti into the Taila. Thus the Taila carries the whole potency of the drug in it. Madhura, Tikta, Kashaya Rasa, Guru, Snighda Guna, Ushna Veerya, Madhura Katu, Vipaka, and Tridoshanashaka Karma of Dashamoola Taila acts on Artavkshaya by its Dravya, Guna, and Prabhava. It has being proven that Dashamoola has anti-inflammatory, analgesic ${ }^{\mathrm{xv}}$ actions

\section{Probable mode of action of Tila Taila:-}

As the base oil for dashmoola is tila taila so the properties of tila taila which help in artavjanan are Tila Taila is of Madhura Rasa and Vipaka, Balya, and Rasayana in Karma; it nourishes and strengthens all the Dhatus, checks Dhatukshaya, and thus alleviates Vata. Snigdha and Guru Guna decreases Rukshata ofVata ${ }^{x v i}$ and with the help of Ushna, Guna, and Veerya it alleviates Vata; the Vikasi property reduces the spasms. Sukskshmata dilates the channels and Vishada prevents stickiness of the channels and thus helps in normal flow of menstrual blood. Garbhashaya Shodhana, Artavajanana properties ${ }^{\text {xvii }}$ of Tila Taila indicates its specific action on genital tract and regulates function of Apana Vayu on particular system. Especially when administered in the form of Basti, Tila Taila directly works on Apana Vata, and by its Yonishula Nashanaaction it works upon Kashtartava..

\section{Results:-}

After receiving this treatment, menstruation started on 3rd day of Uttara Basti. The patient was in continuous follow up. She had two consecutive regular menses with normal flow and no abdominal pain. Inspite of that during her USG on $28^{\text {th }}$ day follicle ovulate even having low ovarian reserve we did her IUI (Intrauterine insemination)

\section{Discussion:-}

According to Ayurveda, Raja is Upadhatu of Rasa and Rakta. Raktasadrushya Raja is formed by Ahara Rasa, so for Niram ahara rasa formation \& Raja Pravartan is function of Apan vayu, so Anulomaka kala Basti was given. And due to the anuloman of apan vayu and revival of its normal functions and her regular menses started and her monthly cycle became regular.

$\checkmark$ Uttara Basti was given for Sthanik Shodhana .

$\checkmark$ Samsodhana ensures as a complete eradication of Vikruta Doshas and increases Agneya condition of the body which is resulting into relative increase in Artava. The apamarg kshar taila causes the lekhan(scrapping )of the localized doshas .so by uttar basti vitiated doshas become normal and periods started .

\section{Conclusion:-}

we can conclude that, as compare to modern view, the holistic approach of Ayurvedic system of medicine because Vasti alone is considered as the major procedure for the anulomana of Vata.Apana Vayu plays an important role along with Vyana gives better relief to the patient from amenorrhoea and infertility. Taila is the best drug for Vata. The function of Anuvasana Vasti is Vatanulomana, thus, it performs its normal function properly. Dashamoola Taila has Tridoshaghna, Parshvashulahara, and Shothahara properties. So it normalize the apan vayu and anuloman occurs and menses became normal.

ACKNOWLEDGEMENT-The authors would like to acknowledge Prof p.k prajapati, Director, IPGT \& RA, GAU, Jamnagar for guidance and support, also to my guide dr.S.B.Donga for their guidance and support

\section{References:-}

1. i Mascarenhas et al. 2012. National, Regional, and Global Trends in Infertility Prevalence Since 1990: A Systematic Analysis of 277 Health Surveys

2. ${ }^{\text {ii }}$ SushruthaSamhita, text with Dalhanateeka,by kaviraj ambikaduttshastri,Chaukhamba Sanskrit sansthan, Varanasi reprint 2006. Su.Sh.2/35,15pp.

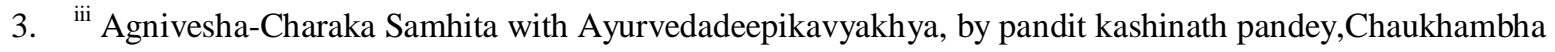
Bharati academy Varanasi Reprint 2008,Cha.si.1/47,973pp

4. ${ }^{\text {iv }}$ Dravya guna vigyana, Acharya Priyavat Sharma volume 2, drug no 374, Chaukhamba Bharati academy Varanasi Reprint 2006, 820pp

5. $\quad{ }^{v}$ Ibidem, volume 2, drug no $375,822 \mathrm{pp}$ 
6. ${ }^{\text {vi }}$ Ibidem, volume 2, drug no 112,282pp.

7. vii Ibidem, volume 2, drug no 111,280pp.

8. viii Ibidem, volume 2, drug no 268,632pp.

9. ix Ibidem, volume 2, drug no 186,455pp.

10. ${ }^{\mathrm{x}}$ Ibidem, volume 2, drug no 192,469pp.

11. ${ }^{\text {xi }}$ Ibidem, volume 2, drug no 84,221pp.

12. ${ }^{\text {xii }}$ Ibidem, volume 2, drug no 86,225pp.

13. ${ }^{\text {xiii }}$ Ibidem, volume 2, drug no 85,233pp.

14. ${ }^{\text {xiv }}$ Agnivesha-Charaka Samhita with Ayurvedadeepikavyakhya, by pandit kashinath pandey,Chaukhambha Bharati academy Varanasi Reprint 2008,Cha.su.4/38,91pp

15. ${ }^{\mathrm{xv}}$ Gupta RA. International Conference on Traditional Medicine, Madras. 1986 Jan 23-25;

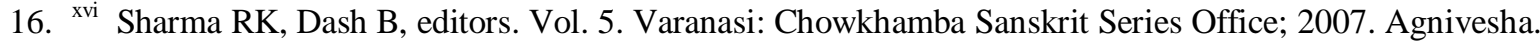
Caraka Samhita; p. 68.

17. ${ }^{\text {xvii }}$ 8. Srikantha Murthy KR, editor. Vol. 1. Varanasi: Chaukambha Orientalia; 2004. Susruta. Susruta Samhita; p. 347. $(\mathrm{Su} / \mathrm{su} / 45 / 112)$ 